\title{
Pricing strategies: who leads and who follows in the air and rail passenger markets in Italy
}

\author{
Angela S. Bergantino ${ }^{1 *}$, Claudia Capozza ${ }^{2}$, Mauro Capurso ${ }^{1,3}$ \\ ${ }^{1}$ Department of Economics, Management and Business Law, University of Bari Aldo Moro, Italy \\ ${ }^{2}$ Ionian Department of Law, Economics and Environment, University of Bari Aldo Moro \\ ${ }^{3}$ Institute for Transport Studies, University of Leeds, UK
}

\begin{abstract}
In this paper, we aim at empirically uncovering the existence of price leadership in the passenger transport market, whose oligopolistic structure facilitates the strategic interaction among companies, with price being one of the principal elements of competition. The strategic interaction is particularly favoured by the fact that prices are easily observable online by all competitors. The analysis focuses on selected Italian city-pair markets that differ from one another with respect to the degree of inter and intra-modal competition and to the characteristics of the transport services provided. We exploit this heterogeneity to study transport operators' strategic interactions in different competitive environments. We find evidence of the existence of price leadership, even though results differ across city-pair markets. In particular, it emerges that the incumbent operator, in either the air or the rail sector, always holds the role of leader.
\end{abstract}

Keywords: Parole chiave.

\section{Introduction}

Oligopolistic markets are often characterised by strategic interactions among competing firms. A form of strategic interaction is price leadership: it occurs when a principal firm establishes the price first, with the other firms in the market being followers. If the principal firm has the largest market share, the price leadership is of a dominant type; if this is not the case, price leadership could be either collusive, if the price is higher than the competitive level, or barometric, if the price is around the competitive level.

From a theoretical viewpoint, price leadership has been widely investigated by scholars. Deneckere and Kovenock (1992) provide the theoretical foundation for the dominant price leadership overcoming the limitations of previous literature, taking as given that large firms act as price leaders and small firms are passive. By introducing the strategic interaction among firms in a duopolistic framework, they show that the high capacity firm becomes the leader and the low capacity firm strictly prefers to be

\footnotetext{
*Corresponding author: Angela Stefania Bergantino (angelastefania.bergantino@uniba.it).
} 
the follower. Cooper (1997) develops a model for the barometric price leadership, showing that under asymmetric information, the informed firm play the role of leader. From Rotemberg and Saloner (1990), some contributions demonstrate that price leadership facilitates collusion because a price increase serves as signal to the other firms to raise their prices (see, also, Ishibashi, 2008). Mouraviev and Rey (2011) prove that price leadership enhances the sustainability of collusion by making easier to punish deviations by the leader. Maskin and Tirole (1988), in a seminal paper later extended by Eckert (2003) and Noel (2008), show that, in equilibrium, the strategic interaction can generate the Edgeworth price cycle. Starting from a price higher than the marginal cost, firms sequentially undercut each other prices to increase their market share. The undercutting continues until the price lowers to the marginal cost. At this point, one firm increases its price and the other firm certainly follows the price rise. When the price is restored to a high level, a new phase of undercutting starts again.

While theoretical evidence on price leadership abounds, the empirical evidence is relatively limited, and tries to prove the existence of price leadership in the observed market. Most empirical papers on price leadership concentrate on the gasoline market for testing the Edgeworth price cycle theory. Noel (2007) and Atkinson (2009) provide some evidence of price leadership in the price restoring phase. More recently, Lewis (2012) performs a comprehensive analysis including 52 cities in the United States. His results reveal a great deal of both within and across market price coordination and price leadership in the gasoline market. Seaton and Waterson (2013) propose a narrow definition of price leadership, occurring when a price change by the leader is followed in a short period by the other firm, which makes a price change of the same monetary amount on the same product. They test this definition of price leadership using data on prices for two key players in the British supermarkets industry. They find considerable evidence of price leadership and, specifically, they observe more leadership in price reduction than in price rise.

This paper contributes to this strand of research. We empirically investigate the price leadership in the passenger transport market, whose oligopolistic structure facilitates strategic interactions among firms. To the best of our knowledge, the passenger transport market has never been explored with this purpose.

Strategic interactions in this market seem particularly favoured by the fact that prices are easily observable online by all competitors. By reducing information asymmetries, the price turns out to be a more important determinant during transactions, even when products and services are not completely homogeneous.

In this paper, we explore the Italian passenger transport market, a meaningful case study since both the air and the rail transport are fully liberalised, and, on some citypairs, competition occurs both within and between modes. For the empirical analysis, we selected three of these city-pairs, namely Rome-Bari, Rome-Milan, and RomeVenice. Each city-pair shows some distinctive features, with respect to the transport companies and the service provided, leading to different competitive environments. This heterogeneity enables us to study the strategic interactions in price setting, and thus the existence of a leader-follower relationship, under different competitive conditions. Moreover, we aim at ascertaining whether the leader-follower relationship changes or emerges during peak hours, when demand is thicker. Indeed, the increased demand of 
transport services during peak hours certainly leads transport companies to adapt their pricing, ${ }^{1}$ but it might also modify the strategic interaction among competing companies.

The database we construct is unique and not replicable. One-way fares have been collected from transport companies' websites by simulating the purchase of tickets, starting from 30 days prior to departure, for 379 combinations of airline and railway services operated from November 2015 to June 2016 on the three city-pairs. To identify possible leader-follower relationships, panel vector auto-regressive models (PVAR) are estimated. The Granger (1969) test would allow us to uncover any causal relations among daily percentage changes of fares of all transport companies (both airlines and railway companies), in each of the observed city-pair markets.

The remainder of the paper is as follows. In Section 2 we describe the city-pair markets under investigation. The literature on pricing strategies in the passenger transport market is surveyed in Section 3. In Section 4 we describe the data collection, while in Section 5 we illustrate the empirical model constructed for the analysis of price leadership. In section 6 we show the results, and finally, in section 7 we draw some conclusions.

\section{The Italian city-pair markets}

In Italy, the passenger transport market appears to be rather competitive. Across citypairs, we can observe competition between airlines, competition between railway companies, and competition between airlines and railway companies (i.e., intermodal competition). There is a good number of airlines, with Alitalia being the incumbent and (still) monopolist on some city-pairs. However, what makes the Italian passenger transport market more interesting is the presence of a mature, on-track, competition in the high-speed rail (HSR) market since 2012. While competition between airlines is quite common worldwide, competition between railways is certainly not. ${ }^{2}$

Following the liberalisation process of the railway sector in Europe, Italy has opened up competition in the high-speed domestic transport to any licensed operator and, currently, it is the only country where two companies provide high-speed rail (HSR) services on some city-pairs (Bergantino, 2015 and 2017). ${ }^{3}$ The private company Nuovo Trasporto Viaggiatori (NTV) has entered the market in 2012. It began providing HSR services on the Rome-Milan corridor in direct competition with Trenitalia, the incumbent state-owned company. In later years NTV entered other city-pair markets, but it has limited its activity only to the HSR segment.

The development of the HSR network over the past decades and the recent entry of NTV have fostered the intermodal competition between airlines and railway companies. Indeed, flights and train rides are considered substitutes when the total travelling time (pure travelling time plus access/egress time) is quite similar, preferably less than 4 hours, and the distance from origin to destination is between 200 and $800 \mathrm{~km}$ (Button,

\footnotetext{
${ }^{1}$ The intertemporal dynamics in the pricing of airline and train companies with the approximation of the departure date has been widely demonstrated (Gaggero and Piga, 2010; Alderighi and Piga, 2010; Bergantino and Capozza, 2015a, 2015b; Bergantino et al. 2015).

${ }^{2}$ See Bergantino (2015) for a detailed discussion on the changes that the European railway market has undergone in the recent decades.

${ }^{3}$ After a series of legislative initiatives by the European Commission to achieve the gradual liberalisation and market-opening process, the $3^{\text {rd }}$ railway package led to the complete open access for international passenger operators.
} 
2012). Therefore, on short-medium haul city-pairs connected with HSR, a strong intermodal competition might take place. However, in Italy the railway network is not equally developed on the territory. HSR services are provided by Trenitalia and NTV in the north-central Italy. The southern Italy is mostly served by Trenitalia, that provides high-capacity services (HC), which are faster than conventional services but are not high speed services.

The combination of all these elements results in different competitive environments across city-pair markets. This heterogeneity can be exploited for studying the strategic interaction in price setting, and thus the existence of leader-follower relationships, under different market conditions. Moreover, we can understand whether the strategic interaction occurs only within airlines and only within railway companies or, instead, if it also occurs between airlines and railway companies.

We focus the empirical analysis on three selected city-pairs, namely Rome-Bari, Rome-Milan, and Rome-Venice, exhibiting different competitive environments. For each city-pair market, we report in Table 1 the companies providing transport services together with the average in-vehicle travelling time.

Table 1. Average in-vehicle travelling time.

\begin{tabular}{|c|c|c|c|c|c|}
\hline \multirow{2}{*}{ City-pair } & \multicolumn{3}{|c|}{ Airline companies } & \multicolumn{2}{|c|}{ Railway companies } \\
\hline & Alitalia & Ryanair & EasyJet & Trenitalia & $N T V$ \\
\hline Rome - Bari & $1 \mathrm{~h} 05 \mathrm{~min}$ & $1 \mathrm{~h} 5 \mathrm{~min}$ & & $4 \mathrm{~h} 02 \mathrm{~min}$ & \\
\hline Bari - Rome & 1h $2 \min$ & 1h $5 \mathrm{~min}$ & & 4h $04 \mathrm{~min}$ & \\
\hline Rome - Venice & 1h $03 \mathrm{~min}$ & & & $3 \mathrm{~h} 38 \mathrm{~min}$ & $3 \mathrm{~h} 43 \mathrm{~min}$ \\
\hline Venice Rome & 1h $04 \mathrm{~min}$ & & & $3 \mathrm{~h} 40 \mathrm{~min}$ & $3 \mathrm{~h} 41 \mathrm{~min}$ \\
\hline Rome - Milan & $1 \mathrm{~h} 10 \mathrm{~min}$ & & $1 \mathrm{~h} 20 \mathrm{~min}$ & $3 \mathrm{~h} 07 \mathrm{~min}$ & $3 \mathrm{~h} 13 \mathrm{~min}$ \\
\hline Milan - Rome & $1 \mathrm{~h} 10 \mathrm{~min}$ & & $1 \mathrm{~h} 20 \mathrm{~min}$ & $3 \mathrm{~h} 11 \mathrm{~min}$ & $3 \mathrm{~h} 08 \mathrm{~min}$ \\
\hline
\end{tabular}

Source: Authors' elaboration on data available on companies' websites.

The Rome-Milan city-pair market has the greatest number of companies, two airlines (Alitalia and EasyJet) and two railway operators (Trenitalia and NTV). Moreover, the total travelling time of air and rail transport basically matches, given that about two hours should be added to the in-flight travelling time to account for the access/egress time.

On the Rome-Bari city-pair market there are two airlines, Alitalia and Ryanair, flying on the same origin-destination (i.e., the same airports) and one railway company, Trenitalia. However, the total travelling time does not perfectly match between the two transport modes, since Trenitalia provides HC services (not high-speed). Instead, on the Rome-Venice city-pair market there is only Alitalia and two railway companies, Trenitalia and NTV. In this case, the total travelling time of air and rail transport is very similar.

Overall, the Rome-Bari is the city-pair market that exhibits the relatively milder intermodal competition, and by this it can be considered as the less competitive one. Using the same reasoning, the Rome-Venice city-pair market show more competition. Although there is only one airline flying, there are two railway companies that directly link the two city-centres with a totalling time that equals that of the air service. Finally, the Rome-Milan city-pair market is the most competitive since it has the largest number of companies, airlines and railway companies, whose total travel times perfectly match. 
In Table 2 we report some statistics on the daily number of transport services provided by each company on the observed city-pairs in the period under investigation (November 2015 to June 2016), and indications on aircrafts' and trains' capacity.

Alitalia and Trenitalia, the incumbent companies in the air and in the rail sector respectively, show a greater average daily frequency compared to other companies in their specific transport sector. The same companies have also the greater capacity in terms of the number of seats. Considering the discussion in the previous section, Alitalia and Trenitalia might be considered the potential leaders in the observed city-pair markets.

Table 2. Daily frequency and number of seats.

\begin{tabular}{|c|c|c|c|c|c|c|c|c|c|c|c|}
\hline \multirow[b]{2}{*}{ City-pair } & & \multicolumn{2}{|c|}{ Alitalia } & \multicolumn{2}{|c|}{ Ryanair } & \multicolumn{2}{|c|}{ EasyJet } & \multicolumn{2}{|c|}{ Trenitalia } & \multicolumn{2}{|l|}{ NTV } \\
\hline & & $\begin{array}{c}\text { Daily } \\
\text { frequency }\end{array}$ & Seats & $\begin{array}{c}\text { Daily } \\
\text { frequency }\end{array}$ & Seats & $\begin{array}{c}\text { Daily } \\
\text { frequency }\end{array}$ & Seats & $\begin{array}{c}\text { Daily } \\
\text { frequency }\end{array}$ & Seats & $\begin{array}{c}\text { Daily } \\
\text { frequency }\end{array}$ & Seats \\
\hline \multirow[t]{3}{*}{ Rome-Bari } & Mean & 5 & & 2.2 & & & & 3.5 & & & \\
\hline & Min & 4 & $138-200$ & 1 & 189 & & & 3 & 489 & & \\
\hline & Max & 6 & & 3 & & & & 4 & & & \\
\hline \multirow[t]{3}{*}{ Bari-Rome } & Mean & 4.7 & & 2.2 & & & & 3.6 & & & \\
\hline & Min & 4 & $138-200$ & 1 & 189 & & & 3 & 489 & & \\
\hline & Max & 5 & & 3 & & & & 4 & & & \\
\hline \multirow[t]{3}{*}{ Rome-Venice } & Mean & 6.4 & & & & & & 20.2 & & 3.8 & \\
\hline & Min & 4 & $138-200$ & & & & & 18 & $432-600$ & 3 & 460 \\
\hline & Max & 7 & & & & & & 23 & & 5 & \\
\hline \multirow[t]{3}{*}{ Venice-Rome } & Mean & 6.1 & & & & & & 18.5 & & 3.7 & \\
\hline & Min & 5 & $138-200$ & & & & & 17 & $432-600$ & 3 & 460 \\
\hline & Max & 7 & & & & & & 21 & & 4 & \\
\hline \multirow[t]{3}{*}{ Rome-Milan } & Mean & 25.2 & & & & 1.8 & & 44.7 & & 16.8 & \\
\hline & Min & 16 & $138-200$ & & & 1 & $156-180$ & 43 & $500-600$ & 13 & 460 \\
\hline & Max & 28 & & & & 2 & & 48 & & 20 & \\
\hline \multirow[t]{3}{*}{ Milan-Rome } & Mean & 24.9 & & & & 1.8 & & 45.3 & & 17.2 & \\
\hline & Min & 12 & $138-200$ & & & 1 & $156-180$ & 44 & $500-600$ & 16 & 460 \\
\hline & Max & 27 & & & & 2 & & 48 & & 18 & \\
\hline
\end{tabular}

Source: Authors' elaboration on data available on companies' websites.

\section{Literature review}

In this section we discuss the empirical literature on pricing behaviour in the passenger transport market, started by Borenstein (1989) for the airline industry. Considering US routes, Borenstein (1989) shows that the ability of raising fares by an airline company is strongly influenced by the market share held both at route-level and at airport level. Consistent results are found on European markets (Bachis and Piga, 2007 and Gaggero and Piga, 2010), where fares appear to be higher in more concentrated markets. Brueckner et al. (2013) provide a comprehensive analysis on the effect of competition on airline fares in domestic US markets, finding that competition has a downward impact of fares and, to a greater extent, the competition from low-cost airlines.

A related strand of research focuses on price discrimination. Early papers by Borenstein and Rose (1994) and Stavins (2001) on the US industry find strong empirical evidences about the use of price discrimination strategies by airlines, particularly in the most competitive markets. Recent works exploring the inter-temporal price discrimination show that fares follow a non-monotonic path over the booking day 
(Alderighi and Piga, 2010 and Bergantino and Capozza, 2015a). Also, Gaggero and Piga (2011) find that inter-temporal price discrimination is applied more in less competitive markets by airlines on Ireland-UK routes, whereas Bergantino and Capozza (2015a) reach the opposite result on Italian domestic routes.

As HSR services become more widely available all over the world and are perceived as a closer substitute to the air transport, their competitive pressure on airlines increases. Therefore, the research scope on pricing behaviour has been enlarged, considering also the effects of inter-modal competition on airline and railway fares.

Bergantino et al. (2015) find that airlines significantly reduce fares on the RomeMilan line when flights are in direct competition with HSR services. Moreover, Bergantino and Capozza (2015b) show that, for Italian city-pairs, airlines set higher fares when the inter-modal competition is limited. The non-monotonic distribution of fares over booking days is more pronounced in presence of inter-modal competition to better segment the market and to extract a larger part of passenger surplus. Capozza (2016) measures the effect of rail travel time on airline fares and finds that airline fares are increasing in rail travel time: airlines feel the competitive pressure from rail services as rail services become faster and, thus, closer substitutes to airline services.

Wei et al. (2016) use the difference-in-difference approach to show that, right after the opening of the Jing-hu HSR line linking Beijing to Shanghai, the average airline fares on routes covered by this new HSR service markedly felt. This result varies depending on the pre-existing market structure. The average fares decrease the most on those routes served by two airlines (duopoly) and less in those with more than two airlines (oligopoly), followed by the routes in which there is only one airline (monopoly).

Looking at the impact of inter-model competition on HSR fares in France, where HSR services are provided by a monopolistic company constrained by price-cap regulation, Perennes (2014) shows that the presence of airline competition reduces HSR fares, thus preventing the railway company to behave as a monopolist.

Overall, there is an extensive literature on pricing behaviour in the transport industry. The discussion outlined above confirms that there is plentiful evidence that airlines and railway companies modify their pricing strategies depending on the degree of competition in the market. However, to our knowledge, there is a lack of studies investigating the causal relationship between fares charged by all companies competing on the observed markets. This paper fills this gap by shedding light on strategic interactions in price setting, with the aim of testing for the existence of leader-follower relationships among airlines and railway companies.

\section{The empirical strategy}

To identify the existence of price leadership we implement the panel vector autoregressive (PVAR) modelling introduced by Holtz-eakin et al. (1988). ${ }^{4}$

\footnotetext{
${ }^{4}$ PVAR modelling has been widely used in macroeconomics and finance (see Canova and Ciccarelli, 2013 for a review), whereas a very few studies use this methodology in microeconomics and industrial organization to analyse firm pricing behaviour. Actually, there are several applications of VAR modelling to the real estate sector (Hannah et al., 1993, Miller and Page, 2006, and Deng et al., 2009), to the ecommerce product pricing (Kauffman and Wood, 2007), to pricing strategy of milk processors (Graubner et al., 2011) and to fresh products' pricing of leading supermarket chains (Revoredo-Giha and Renwick,
} 
Pooling cross-sectional units have some advantages: first, the assumption of time stationarity can be relaxed because the presence of a large number of cross-sectional units allows for lag coefficients that vary over time; second, the asymptotic distribution theory for a large number of cross-sectional units does not require the vector autoregression to satisfy the usual conditions that rule out unit and explosive roots. ${ }^{5}$

We specify the following $k$-variate PVAR model represented by the following system of linear equations:

$$
\Delta \mathrm{P}_{\mathrm{it}}=\mathrm{A}_{0}+\mathrm{A}(L) \Delta \mathrm{P}_{\mathrm{it}}+v_{\mathrm{i}}+\mathrm{d}_{\mathrm{it}}+\varepsilon_{\mathrm{it}}
$$

where:

$$
i \in\{1, \ldots, \mathrm{N}\}, \mathrm{t} \in\left\{1, \ldots, \mathrm{T}_{i}\right\}
$$

- the cross-sectional dimension $i$ is a unique combination of transport services provided by competing airlines and railway companies;

- $t$ is the time dimension defined by the booking days before departure;

- $\Delta \mathrm{P}_{\text {it }}$ is the vector of dependent variables constructed as daily percentage change of fares: $\left(P_{i t}-P_{i t-1}\right) / P_{i t-1} \times 100$;

- $L$ is the lag operator;

- A represents the matrices of parameters to be estimated;

- $v_{\mathrm{i}}$ are dependent variable-specific fixed effects;

- $\mathrm{d}_{\mathrm{it}}$ are the company-specific time effects (i.e. booking day dummies) introduced for capturing the inter-temporal pricing behaviour of each transport company and the gradual increase in the load factor resulting from departure approaching;

- $\varepsilon_{\text {it }}$ is the idiosyncratic error term.

The dependent variable is defined as the daily percentage change of fares for two main reasons. First, it is appropriate for the investigation of price leadership, since we can test whether a fare change by one company is followed by a fare change by the other companies. Second, the series of fares might contain a trend, due to the date of departure that progressively approaches, that we can remove with first differencing. This is verified through appropriate testing.

Because of the correlation between $v_{i}$ and the regressors we apply the Helmert transformation (i.e., forward mean-difference) to remove $v_{i}$. The system of equation is estimated by GMM using the lags of the regressors as instruments (Arellano and Bover, 1995; Blundell and Bond, 1998). We estimate three PVAR models, one for each of the selected city-pair markets.

\subsection{Pre - estimation: Model (lag) selection criteria}

To define the optimal lag order, we use the moment and model selection criteria (MMSC) for GMM models proposed by Andrews and Lu (2001), resembling the widely-used Bayesian (BIC), Akaike (AIC) and Hannan-Quinn (HQIC) information criteria, based on Hansen's J (1982) test statistics of over-identifying restrictions. Andrews and $\mathrm{Lu}$ (2001) conduct a Monte Carlo experiment to evaluate the finite sample performance of the model selection criteria. The MMSC BIC is found to perform better

2012). However, all these applications use only time-series data (i.e. they not have any cross-sectional dimension).

${ }^{5}$ See Holtz-eakin et al., 1988, page 1373. 
in selecting the correct model and moment conditions in a variety of contexts when dynamic panel data are used. For this reason, we include the number of lag for which the MMSC BIC point to a lower value.

\subsection{Post - estimation: Granger causality test}

The Granger (1969) causality test ascertains whether the lags of the endogenous variables enter the equation of another endogenous variable (Enders, 2008). In this paper, the Granger causality allows to understand if a fare change by one company (represented on the right-hand-side of equation [1]) Granger-causes, in the subsequent period, a fare change by the other company (represented on the left-hand-side). We can end up with the following scenarios:

1. if a unidirectional and positive causality is found, then a fare change by one company (the leader) causes a fare change in the same direction by one or more companies in the subsequent period (the followers). This would suggest that a leader-follower relationship exists;

2. if a unidirectional and negative causality is found, then a fare change by one company causes a fare change in the opposite direction by the one other or more companies in the subsequent period. This would be the indication of a weak form of oligopolistic competition;

3. if a bidirectional and positive causality is found, then a fare change by one company causes a fare change in the same direction by the one other or more companies in the subsequent period, but also the vice-versa happens. This would be indicative of both strong competition and collusion. In this case, the average price on the market needs to be considered to ascertain whether competition or collusion is occurring;

4. if a bidirectional and negative causality is found, then a fare change by one company causes a fare change in the opposite direction by the one other or more companies in the subsequent period, but also the vice-versa happens. This would be the indication of a non-collusive oligopolistic competition;

5. if a bidirectional causality with opposite signs is found, a strategic interaction in price setting is occurring, but it is difficult to exactly determine which form of competition is taking place;

6. finally, if Granger causality does not exist, the companies are supposed to be independent in their pricing strategies.

\section{Data collection and preliminary analysis}

The database we construct is unique and not replicable. One-way cheapest fares have been collected by simulating the purchase of tickets from each transport company's website for the 30 days prior to departure for 379 combinations of airline and railway services operated from November 2015 to June 2016 on the three city-pairs: Rome-Bari and return, Rome-Venice and return, and Rome-Milan and return. The air and rail transport services included in the database are supposed to be in competition because, as already mentioned, the total travelling time (pure travelling time plus access/egress time) is similar - less than 4 hours for both modes -, and the distance is between 200 and 800 $\mathrm{km}$.

To ensure a good coverage of the typical trips on these corridors, several business services (same day return) and leisure services (short and long weekend visits) have been identified (see Table 3 ). 
Table 3. Details of the data collection.

\begin{tabular}{|c|c|c|c|}
\hline Origin-Destination & Type & \multicolumn{2}{|c|}{ Departure date } \\
\hline \multirow[t]{3}{*}{ Bari - Rome, and return } & \multirow[t]{3}{*}{$\begin{array}{l}\text { Same day return, } \\
\text { business }\end{array}$} & 10 November 2015; & 3 December 2015; \\
\hline & & 15 December 2015; & 2 February 2016; \\
\hline & & 19 May 2016; & 7 June 2016. \\
\hline Rome - Bari, and return & Long weekend, leisure & 4 to 8 December 2015 & 2 to 5 June 2016. \\
\hline Rome - Bari, and return & Short weekend, leisure & 12 to 14 February 2016 & $\begin{array}{l}29 \text { April to } 1 \text { May } \\
2016 .\end{array}$ \\
\hline \multirow[t]{2}{*}{ Venice - Rome, and return } & Same day return, leisure & 10 November 2015; & 3 December 2015; \\
\hline & & 15 December 2015; & 7 June 2016. \\
\hline \multirow[t]{2}{*}{ Rome - Venice, and return } & Long weekend, leisure & 2 to 5 June 2016. & \\
\hline & Short weekend, leisure & $\begin{array}{l}11 \text { to } 13 \text { December } \\
2015 \text {; }\end{array}$ & $\begin{array}{l}29 \text { April to } 1 \text { May } \\
2016 \text {. }\end{array}$ \\
\hline \multirow[t]{2}{*}{ Milan - Rome, and return } & Same day return, leisure & 10 November 2015 & 3 December 2015; \\
\hline & & 15 December 2015; & 19 May 2016. \\
\hline \multirow[t]{2}{*}{ Rome - Milan, and return } & Same day return, leisure & 10 November 2015; & 3 December 2015; \\
\hline & & 15 December 2015; & 19 May 2016. \\
\hline Milan - Rome, and return & Long weekend, leisure & 2 to 5 June 2016. & \\
\hline
\end{tabular}

We identify train rides that are in competition with flights as those departing up to one hour before the flights and arriving up to one hour later. This hypothesis was slightly relaxed for the Rome-Bari city-pair, where the number of transport services is lower than other city-pair markets (see Table 2). The same applies to competition among airlines, since the number of flights of the low-cost airline Ryanair is lower than to those of full-service airline Alitalia.

Table 4 shows the average absolute difference, in minutes, among the departing times of competing transport services, distinguishing between the transport modes.

Table 4. Average absolute difference between departing time of competing transport services (in minutes).

\begin{tabular}{lccc}
\hline City-pair & \multicolumn{3}{c}{ Difference between departing time } \\
& Air/Air & Rail/Rail & Air/Rail \\
\hline Rome - Bari & 105 & & 107 \\
Bari - Rome & 89 & 68 & 64 \\
Rome - Venice & & 56 & 52 \\
Venice - Rome & & 19 & 53 \\
Rome - Milan & 84 & 27 & 36 \\
Milan - Rome & 59 & & 39 \\
\hline
\end{tabular}

These figures can be interpreted as a supplementary measure of intra- and inter-modal competition. Indeed, the lower is the difference among departing times, the greater is the degree of substitution of transport services; thus, the greater is the degree of 
competition. Based on this definition, it appears that the Rome Milan city-pair has the greatest degree of competition, while the Rome-Bari city-pair has the lowest.

The average daily fares over the booking days for the transport companies are shown in Figure 1. Alitalia's fares are presented separately from fares set by the other companies. This is done to better appreciate the inter-temporal profile of fares, since the flag airline sets relatively higher fares compared to the other transport companies.
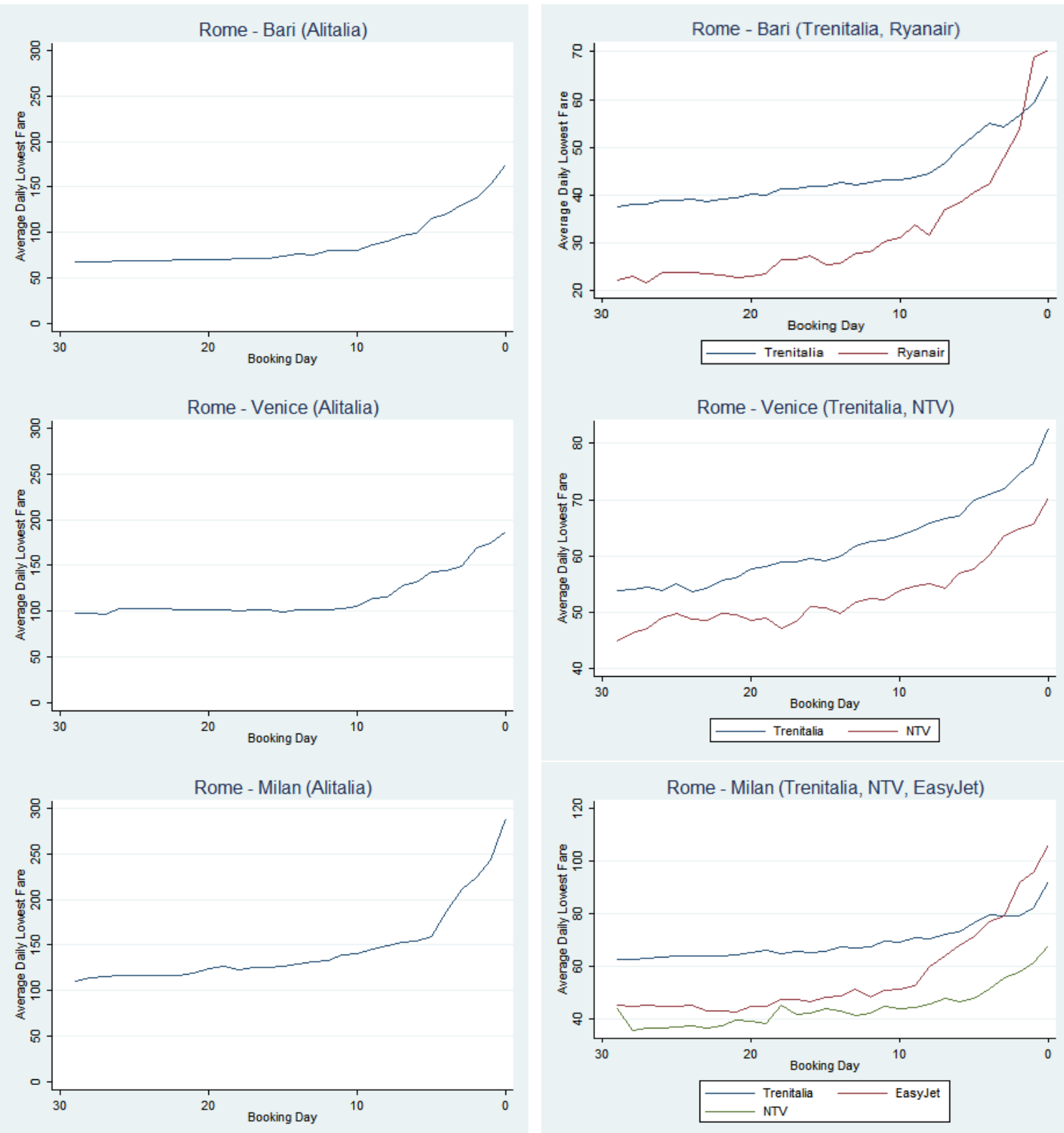

Figure 1. Average daily fares.

The inter-temporal profiles of fares of Alitalia and Trenitalia are smoother compared to the profiles of the other transport companies that, instead, exhibits some high-low price movements. The price differences across companies are also shown by descriptive statistics reported in Table 5. 
Table 5. Descriptive statistics for the average lowest fares.

\begin{tabular}{lccccc}
\hline City-pair & Company & Mean & Std. Dev. & Min & Max \\
\hline \multirow{2}{*}{ Rome - Bari } & Alitalia & 116.03 & 24.91 & 96.34 & 186.32 \\
& Ryanair & 33.24 & 13.06 & 22.38 & 73.05 \\
& Trenitalia & 44.06 & 7.72 & 36.66 & 66.27 \\
& & & & & \\
Rome - Venice & Alitalia & 92.43 & 34.38 & 68.22 & 203.76 \\
& Trenitalia & 62.12 & 7.50 & 53.60 & 82.79 \\
& NTV & 53.03 & 6.23 & 44.86 & 70.39 \\
& & & & & \\
Rome - Milan & Alitalia & 147.83 & 40.76 & 110.93 & 282.81 \\
& EasyJet & 59.39 & 16.84 & 45.52 & 109.07 \\
& Trenitalia & 70.89 & 6.49 & 63.75 & 92.12 \\
& NTV & 45.64 & 6.94 & 37.48 & 67.58 \\
\hline
\end{tabular}

Figure 2, 3 and 4 shows the average daily change of fares by transport companies on the considered city-pairs, respectively.

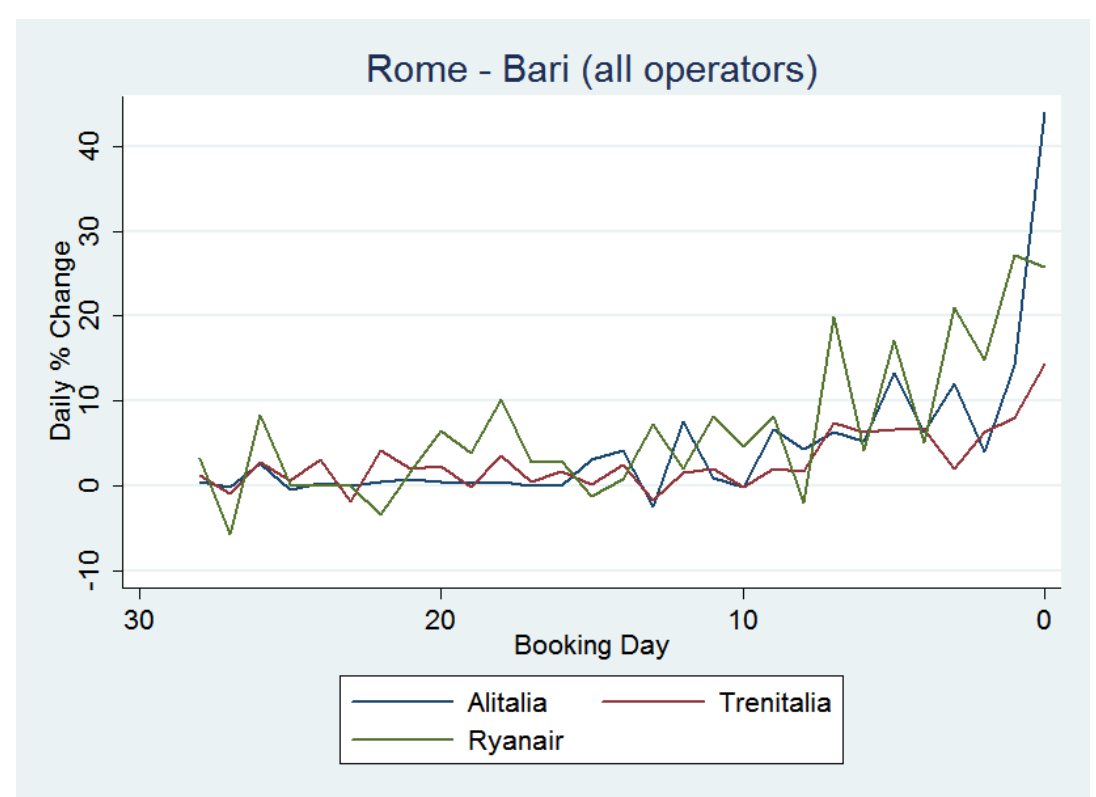

Figure 2. Average daily change of fares on Rome-Bari. 


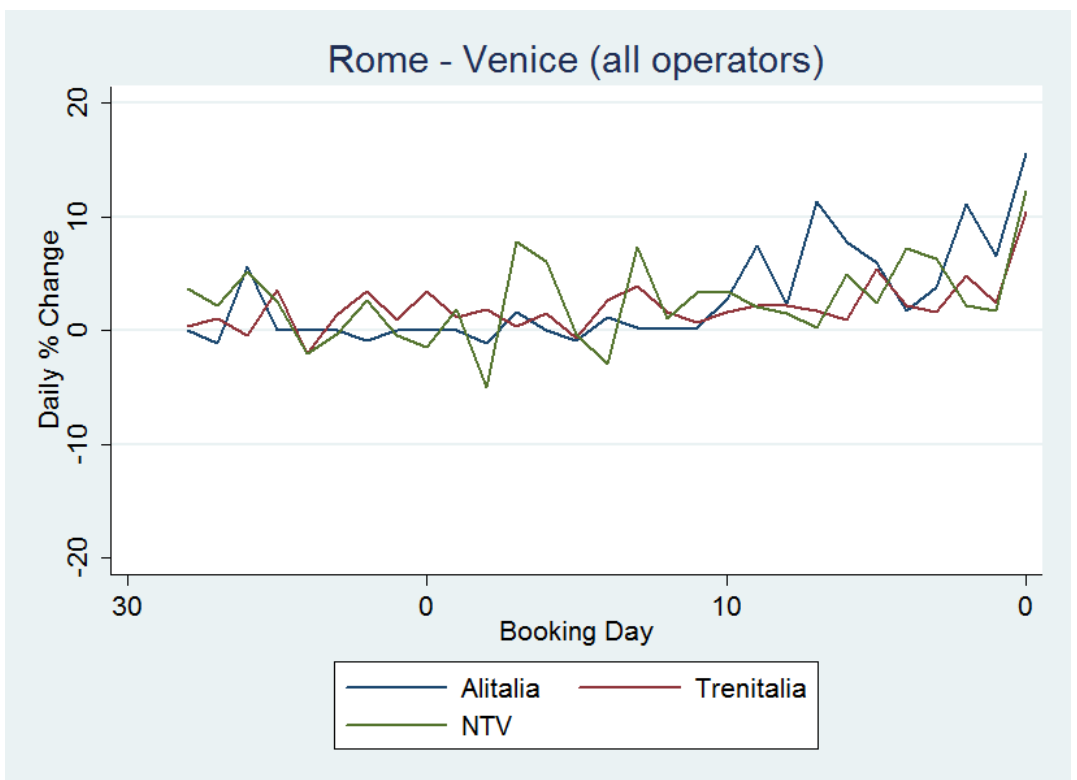

Figure 3. Average daily change of fares on Rome-Venice.

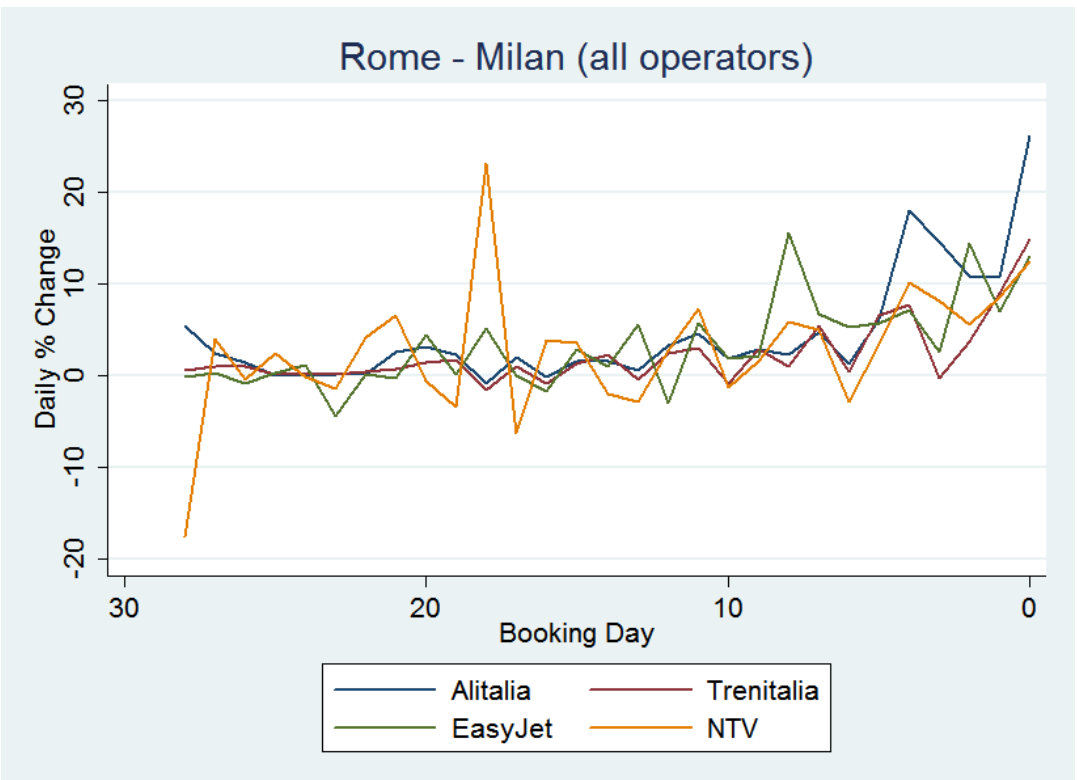

Figure 4. Average daily change of fares on Rome-Milan.

On the Rome-Bari city-pair, Ryanair is the company showing, on average, more frequent and wider price changes over the booking days. Alitalia's price changes are modest until around one week before departure, becoming henceforth larger that those of Ryanair. Instead, Trenitalia shows contained price changes over the period.

On the Rome-Venice city-pair, NTV exhibits, on average, more frequent and wider price changes over the booking days. As before, Alitalia's price changes are modest until one week before departure, becoming larger in the last week, whereas Trenitalia shows minor price changes over the period. 
On the Rome-Milano city-pair, price changes by Alitalia and Trenitalia move almost identically over the booking days, except for the last week in which they diverge. EasyJet and NTV show the broader price changes.

The discussion above is useful to get an idea on how price changes evolve over time. However, the causal relationship can be inferred only from the results of PVAR estimations.

\section{Results}

Before presenting estimation results, we discuss some issues regarding the lag selection and the stability condition.

In Table 6 we show the results of the lag selection procedure using the MMSC BIC.

Table 6. Lag selection.

\begin{tabular}{lccc}
\hline & \multicolumn{3}{c}{ MMSC BIC } \\
& Rome - Bari & Rome - Venice & Rome - Milan \\
\hline lag - 1 & -108.516 & -75.115 & 469.032 \\
lag - 2 & -77.214 & -62.105 & 268.349 \\
lag - 3 & -29.140 & -22.844 & 283.591 \\
lag - 4 & -55.802 & -46.926 & -31.580 \\
\hline
\end{tabular}

Looking at the lowest value of MMSC BIC, the optimal number of lags for RomeBari and Rome-Venice city-pairs is one, whereas the optimal number of lags for RomeMilan city-pair is four.

The stability condition of PVAR models is verified if the modulus of each eigenvalue of the companion matrix is strictly less than one. ${ }^{6}$ The stability implies that the PVAR is invertible, has an infinite-order vector moving-average representation, providing known interpretation to the impulse-response functions (IRFs). Figure 5 shows that the stability condition is satisfied since all the eigenvalues lie inside the unit circle.
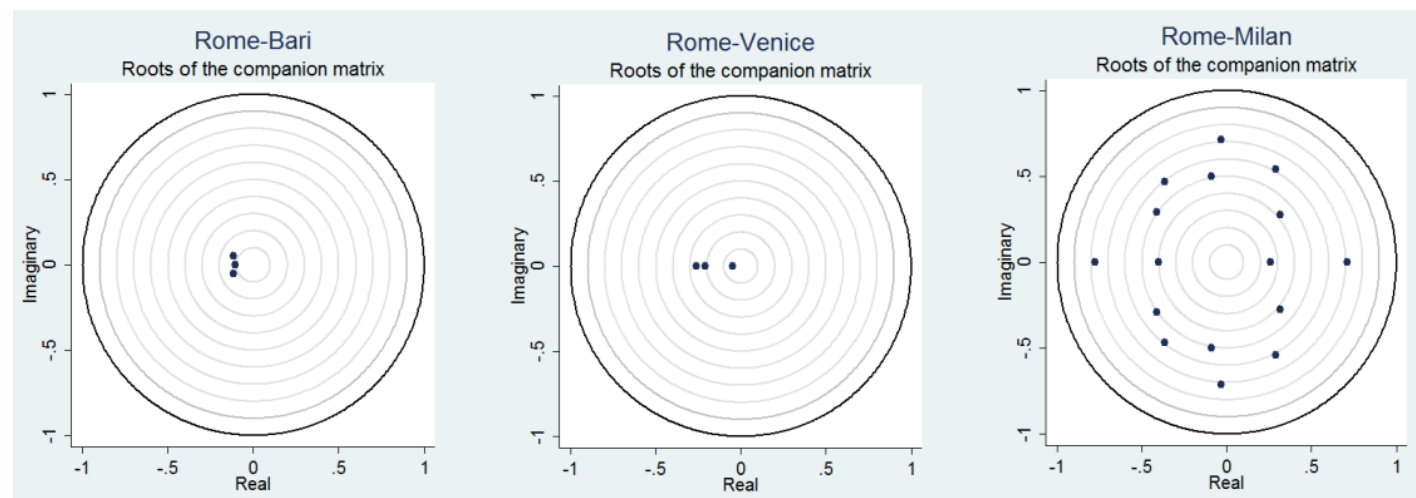

Figure 5. Stability condition of PVAR models.

\footnotetext{
${ }^{6}$ See Hamilton (1994) and Lutkepohl (2005).
} 
From Table 7(a) to Table 7(c), we present the results for estimations together with the Granger causality. ${ }^{7}$ The Granger causality tests for the joint significance of lagged variables. When only the first lag is introduced in the equation, the p-value associated to the related coefficient shows itself the Granger causality.

Starting from Table 7(a), we show the first set of estimates on the Rome-Bari city-pair market.

Table 7(a). Estimation results of PVAR model on the Rome-Bari city-pair market.

\begin{tabular}{llccc}
\hline $\begin{array}{l}\text { Dependent variable: daily } \\
\text { change of the lowest fare }\end{array}$ & $\begin{array}{l}\text { Lagged dependent } \\
\text { variable }(t-1)\end{array}$ & Coefficient & p-value & $\begin{array}{c}\text { Granger Test } \\
(\text { p-value })\end{array}$ \\
\hline Alitalia & Alitalia & -0.054 & 0.411 & \\
& Trenitalia & 0.173 & 0.003 & $8.675(0.003)$ \\
& Ryanair & 0.002 & 0.923 & $0.009(0.923)$ \\
& Alitalia & & & \\
Trenitalia & Trenitalia & -0.037 & 0.105 & $2.623(0.105)$ \\
& Ryanair & 0.002 & 0.839 & $0.041(0.839)$ \\
& & & & \\
Ryanair & Alitalia & -0.019 & 0.692 & $0.157(0.692)$ \\
& Trenitalia & 0.018 & 0.637 & $0.223(0.637)$ \\
& Ryanair & -0.102 & 0.002 & \\
\hline N. observations & 1,932 & & & \\
N. panels & 71 & & & \\
\hline
\end{tabular}

Booking day dummies are always included but not reported.

It emerges a unidirectional and positive causality between Alitalia and Trenitalia. A price change by Trenitalia Granger-causes a price change by Alitalia in the subsequent period in the same direction. This is the evidence of price leadership, where the leader is Trenitalia and the follower is Alitalia. The price changes of Ryanair are neither influenced by nor influence other companies.

This finding is very interesting since the leader-follower relationship occurs between a railway company and an airline company. This might suggest that the two companies compete for the same consumer segment, with Alitalia adapting to the pricing behaviour of Trenitalia.

In Table 7(b), we report the second set of estimates on the Rome-Venice city-pair.

\footnotetext{
${ }^{7}$ We use the Stata package developed by Abrigo and Love (2015) to estimate PVAR models and to implement Granger causality tests and optimal model (lag) selection.
} 
Table 7(b). Estimation results of PVAR model on the Rome-Venice.

\begin{tabular}{llccc}
\hline $\begin{array}{l}\text { Dependent variable: daily } \\
\text { change of the lowest fare }\end{array}$ & $\begin{array}{l}\text { Lagged Dependent } \\
\text { variable }(t-1)\end{array}$ & Coefficient & $p$-value & $\begin{array}{c}\text { Granger Test } \\
(p \text {-value })\end{array}$ \\
\hline Alitalia & Alitalia & -0.040 & 0.313 & \\
& Trenitalia & 0.006 & 0.859 & $0.031(0.859)$ \\
& NTV & 0.047 & 0.038 & $4.299(0.038)$ \\
& Alitalia & -0.023 & 0.178 & $1.818(0.178)$ \\
Trenitalia & Trenitalia & -0.182 & 0.001 & \\
& NTV & -0.031 & 0.02 & $5.379(0.020)$ \\
& & & & \\
NTV & Alitalia & -0.033 & 0.063 & $3.468(0.063)$ \\
& Trenitalia & 0.096 & 0.019 & $5.49(0.019)$ \\
& NTV & -0.301 & 0.000 & \\
\hline N. observations & 2,365 & & & \\
N. panels & 88 & & & \\
\hline
\end{tabular}

Booking day dummies are always included but not reported.

On this city-pair, we find no evidence of price leadership. The results indicate two bidirectional causalities with opposite signs between Alitalia and NTV and between Trenitalia and NTV.

First, a price change by NTV Granger-causes a price change by Alitalia in the subsequent period in the same direction. Moreover, a price change by Alitalia Grangercauses a price change by NTV in the subsequent period in the opposite direction. While Alitalia seems to adapt its pricing to NTV's changes, on the other side NTV differentiates its pricing from Alitalia.

Second, a price change by NTV Granger-causes a price change by Trenitalia in the subsequent period in the opposite direction, but a price change by Trenitalia Grangercauses a price change by NTV in the subsequent period in the same direction. In this case, NTV modifies its pricing following Trenitalia's changes, whereas Trenitalia differentiates its pricing strategy from NTV.

NTV, the new comer, appears to be influenced by both rival companies, although in different ways. Its pricing moves in the same direction of the railway's pricing, whilst it deviates from the airline's pricing. At the same time, the new comer's pricing influences competitors' pricing.

All in all, the Rome-Venice city-pair market appears quite dynamic, with strong strategic interdependencies among players, but none of them is price leader.

In Table 7(c) we present the estimations on the Rome-Milan city-pair market. In this case, two analysis are carried out. The first relates to the full sample of transport services provided; the second is based on restricted sample of transport services, those provided during peak hours. ${ }^{8}$ As explained before, this analysis aims to verifying whether the strategic interaction between transport companies changes when the demand for travel is relatively higher.

\footnotetext{
${ }^{8}$ For airlines, we consider peak-hours flights those departing from the early morning until 8:30 and from 18:00 to 21:00. For rail operators, we consider peak-hours services those running from the early morning until 8:00 and from 17:00 to 20:00.
} 
The estimations on the full sample reveal two unidirectional and positive causalities that could be interpreted as the evidence of price leadership. One involves the two airline companies while the other involves the two railway companies.

First, a price change by Alitalia Granger-causes a price change by EasyJet in the subsequent period in the same direction, but the opposite does not occur. In the specific, the coefficient of the fourth lag is positive and significant, while coefficients of the third to the first lags are not significant. This entails that the reaction of EasyJet to Alitalia's price change does not occur immediately but it takes a few days.

Second, a price change by Trenitalia Granger-causes a price change by NTV in the subsequent period in the same direction, but the opposite does not occur. The coefficients of the third and fourth lags are positive and significant, while coefficients of the second and first lags are not.

Moreover, there are two other intermodal strategic interactions. There is a bidirectional and negative causality between EasyJet and NTV. A price change by EasyJet Granger-causes a price change in the opposite direction by NTV in the subsequent period, but also the vice-versa happens. Between the two companies there is a strong, non-collusive, oligopolistic competition. Moreover, there is a bidirectional causality of opposite signs between EasyJet and Trenitalia. First, a price change by Trenitalia Granger-causes a price change by EasyJet in the subsequent period in the opposite direction. However, a price change by EasyJet Granger-causes a price change by Trenitalia in the subsequent period in the same direction.

Interpreting all these findings together, it emerges that the clearer leader-follower relation is between Alitalia and EasyJet. In fact, between Trenitalia, NTV and EasyJet there is a triangular relationship. Trenitalia influences NTV, which influences and is influenced by EasyJet that, in turn, influences Trenitalia. Alitalia seems to be the only one that influences directly and indirectly competitors' pricing behaviour, but it is influenced by none of them.

Estimations on the subsample of transport services provided during peak hours show that EasyJet, Trenitalia and NTV are influenced by all competitors' pricing behaviour. Particularly, Alitalia's price changes have a positive influence on all competitors' price changes, whereas it is only weakly (positive) influenced by EasyJet, since the coefficient of the third lag of EasyJet's price change is weakly different from zero. We can consider Alitalia as the price leader during peak hours.

All in all, the results highlight the role of leader played by Alitalia in setting prices on the Rome-Milan city-pair markets both in peak and off-peak hours. The fact that Alitalia's fares are considerably higher than those of competitors (see Table 5) strengthens the intuition that the flag carrier is not influence by competitors' pricing behaviour. 
Working papers SIET 2017 - ISSN 1973-3208

Table 7(c). Estimation results of PVAR model on the Rome-Milan.

\begin{tabular}{|c|c|c|c|c|c|c|c|}
\hline \multirow{2}{*}{$\begin{array}{l}\text { Dependent variable: daily } \\
\text { change of the lowest fare }\end{array}$} & \multirow{2}{*}{$\begin{array}{l}\text { Lagged dependent } \\
\text { variable }(t-1 \text { to } t-4)\end{array}$} & \multicolumn{3}{|c|}{ Full Sample } & \multicolumn{3}{|c|}{ Peak hours } \\
\hline & & Coeff. & p-value & Granger Test & Coeff. & $p$-value & Granger Test \\
\hline \multirow[t]{16}{*}{ Alitalia } & Alitalia & -0.157 & 0.000 & & -0.113 & 0.041 & \\
\hline & & -0.090 & 0.017 & & -0.039 & 0.449 & \\
\hline & & 0.085 & 0.010 & & 0.033 & 0.464 & \\
\hline & & -0.068 & 0.003 & & -0.015 & 0.636 & \\
\hline & EasyJet & 0.038 & 0.334 & $4.416(0.353)$ & -0.035 & 0.495 & $10.53(0.032)$ \\
\hline & & 0.072 & 0.079 & & 0.040 & 0.471 & \\
\hline & & 0.080 & 0.073 & & 0.125 & 0.053 & \\
\hline & & 0.007 & 0.853 & & -0.079 & 0.132 & \\
\hline & Trenitalia & -0.044 & 0.218 & $4.12(0.390)$ & -0.053 & 0.407 & $5.237(0.264)$ \\
\hline & & -0.028 & 0.417 & & -0.054 & 0.329 & \\
\hline & & -0.067 & 0.100 & & -0.116 & 0.062 & \\
\hline & & -0.057 & 0.177 & & -0.126 & 0.043 & \\
\hline & NTV & -0.010 & 0.452 & $6.456(0.168)$ & -0.044 & 0.059 & $5.378(0.251)$ \\
\hline & & 0.007 & 0.587 & & -0.009 & 0.575 & \\
\hline & & 0.046 & 0.012 & & 0.025 & 0.425 & \\
\hline & & 0.005 & 0.653 & & -0.025 & 0.083 & \\
\hline \multirow[t]{16}{*}{ EasyJet } & Alitalia & -0.015 & 0.184 & $9.993(0.041)$ & 0.005 & 0.684 & $22.855(0.000)$ \\
\hline & & -0.002 & 0.904 & & 0.064 & 0.000 & \\
\hline & & -0.007 & 0.525 & & 0.032 & 0.071 & \\
\hline & & 0.023 & 0.046 & & 0.039 & 0.006 & \\
\hline & EasyJet & -0.118 & 0.000 & & -0.210 & 0.000 & \\
\hline & & 0.100 & 0.000 & & 0.044 & 0.124 & \\
\hline & & 0.047 & 0.119 & & 0.030 & 0.261 & \\
\hline & & 0.285 & 0.000 & & 0.354 & 0.000 & \\
\hline & Trenitalia & -0.024 & 0.032 & $65.319(0.000)$ & -0.014 & 0.488 & $32.997(0.000)$ \\
\hline & & -0.048 & 0.000 & & -0.056 & 0.002 & \\
\hline & & -0.099 & 0.000 & & -0.104 & 0.000 & \\
\hline & & -0.021 & 0.096 & & -0.053 & 0.002 & \\
\hline & NTV & -0.021 & 0.002 & $73.686(0.000)$ & -0.033 & 0.000 & $52.333(0.000)$ \\
\hline & & -0.046 & 0.000 & & -0.063 & 0.000 & \\
\hline & & -0.056 & 0.000 & & -0.047 & 0.000 & \\
\hline & & -0.029 & 0.000 & & -0.030 & 0.001 & \\
\hline \multirow[t]{16}{*}{ Trenitalia } & Alitalia & 0.027 & 0.214 & $4.934(0.294)$ & 0.091 & 0.005 & $17.903(0.001)$ \\
\hline & & 0.052 & 0.031 & & 0.143 & 0.000 & \\
\hline & & 0.016 & 0.477 & & 0.002 & 0.948 & \\
\hline & & 0.012 & 0.483 & & 0.047 & 0.062 & \\
\hline & EasyJet & 0.026 & 0.423 & $15.143(0.004)$ & -0.019 & 0.689 & $22.319(0.000)$ \\
\hline & & 0.090 & 0.010 & & 0.151 & 0.003 & \\
\hline & & 0.140 & 0.000 & & 0.211 & 0.001 & \\
\hline & & 0.084 & 0.012 & & 0.164 & 0.007 & \\
\hline & Trenitalia & -0.300 & 0.000 & & -0.399 & 0.000 & \\
\hline & & -0.228 & 0.000 & & -0.407 & 0.000 & \\
\hline & & -0.084 & 0.052 & & -0.281 & 0.000 & \\
\hline & & 0.012 & 0.838 & & -0.082 & 0.370 & \\
\hline & NTV & 0.011 & 0.502 & $2.861(0.581)$ & 0.027 & 0.258 & $12.850(0.012)$ \\
\hline & & 0.021 & 0.233 & & -0.016 & 0.551 & \\
\hline & & 0.020 & 0.349 & & 0.078 & 0.002 & \\
\hline & & 0.021 & 0.173 & & 0.023 & 0.307 & \\
\hline \multirow[t]{16}{*}{ NTV } & Alitalia & 0.012 & 0.568 & $5.967(0.202)$ & 0.039 & 0.185 & $9.561(0.048)$ \\
\hline & & -0.011 & 0.656 & & 0.043 & 0.247 & \\
\hline & & 0.000 & 0.987 & & -0.027 & 0.433 & \\
\hline & & 0.037 & 0.042 & & 0.045 & 0.077 & \\
\hline & EasyJet & -0.042 & 0.333 & $50.154(0.000)$ & -0.171 & 0.017 & $28.551(0.000)$ \\
\hline & & -0.048 & 0.302 & & -0.105 & 0.133 & \\
\hline & & -0.144 & 0.001 & & -0.267 & 0.000 & \\
\hline & & 0.164 & 0.005 & & -0.012 & 0.856 & \\
\hline & Trenitalia & 0.036 & 0.162 & $11.474(0.022)$ & 0.121 & 0.002 & $10.222(0.037)$ \\
\hline & & -0.031 & 0.277 & & 0.031 & 0.462 & \\
\hline & & 0.060 & 0.074 & & 0.057 & 0.198 & \\
\hline & & 0.052 & 0.049 & & 0.046 & 0.240 & \\
\hline & NTV & -0.225 & 0.000 & & -0.195 & 0.000 & \\
\hline & & -0.135 & 0.000 & & -0.108 & 0.000 & \\
\hline & & -0.136 & 0.000 & & -0.151 & 0.000 & \\
\hline & & -0.086 & 0.000 & & -0.089 & 0.004 & \\
\hline N. observations & & 4739 & & & 2477 & & \\
\hline N. panels & & 220 & & & 113 & & \\
\hline
\end{tabular}

Booking day dummies are always included but not reported. 


\section{Conclusions}

In this paper, we empirically explore the strategic interaction in price setting behaviour in the Italian passenger transport market to uncover the existence of price leadership. This market is well suited to the research purpose given its oligopolistic structure, with pricing being one of the principal elements of competition among transport companies. Moreover, the selected city-pair markets differ from one another with respect to the number of competing companies and to the degree of substitutability of the transport services offered. We exploit this heterogeneity to study the price leadership in different competitive environments. Furthermore, the Italian market is the only one in Europe where on-track competition in HSR services is effective, which allows to observe pricing behaviour when also intermodal competition with airlines occurs.

The contribution of our work is threefold. First, we contribute to the empirical research on price leadership, which is quite limited. Second, we contribute to the literature on pricing strategies in the transport industry. Although this research field is widely explored, there is no paper that studies the leader-follower relationship. Third, the PVAR model is used as an econometric tool to address microeconomic topic, whereas this methodology is mostly used to analyse the interdependence among series of macroeconomic and financial variables, while the application to microeconomic variables is rather scarce.

Our results provide evidence of the existence of price leadership in two of the three city-pair markets observed. Interestingly, the strategic interaction occurs also among companies operating in different transport sectors. We do not find a result that is common to all the observed markets. On the contrary, results differ across city-pair markets: one company can be a leader on a given city-pair market and a follower on another. The heterogeneity of the results can be explained by the different competitive environment characterising each citypair market. All in all, what emerges is that in the analysed markets the incumbents dominate. The role of leader is held, in fact, on a city-pair market by Trenitalia, and on another city-pair market by Alitalia, which are the incumbent companies in the rail sector and in the air sector, respectively. Finally, Alitalia appears to be the leader also in peak hours, when demand is thicker. 


\section{References}

Abrigo, M. R., Love, I. 2015. Estimation of panel vector autoregression in Stata: A package of programs.

Alderighi, M., Piga, C.A. 2010. On-line Booking and Revenue Management: Evidence from a Low-Cost Airline. Review of Economic Analysis, 2(3): 272-286.

Andrews, D.W.K., Lu. B. 2001. Consistent model and moment selection procedures for GMM estimation with application to dynamic panel data models. Journal of Econometrics, 101: 123-164.

Arellano, M., Bover, O. 1995. Another look at the instrumental-variable estimation of errorcomponents models. Journal of Econometrics 68: 29-52.

Atkinson, B. 2009. Retail Gasoline Price Cycles: Evidence from Guelph, Ontario Using BiHourly, Station-Specific Retail Price Data. Energy Journal, 30(1): 85-109.

Bergantino, A.S., 2015. Incumbents and new entrants. In Rail Economics, Policy and Regulation in Europe, Finger M., Messulam P. (ed.), Edward Elgar, London.

Bergantino, A.S., 2017, Open Access Passenger Rail Competition: the case of Italy, proceedings of the Colloque on Concurrence et régulation: Quelles perspectives pour le transport ferroviaire? Paris, 29th June 2017.

Bergantino, A. S., Capozza, C., Capurso, M. 2015. The impact of open access on intra-and inter-modal rail competition. A national level analysis in Italy. Transport Policy, 39, 77-86.

Bergantino, A.S., Capozza, C. 2015a. Airline Pricing Behavior under Limited Inter-modal Competition. Economic Inquiry, 53(1): 700-713.

Bergantino, A. S., Capozza, C. 2015b. One price for all? Price discrimination and market captivity: Evidence from the Italian city-pair markets. Transportation Research Part A: Policy and Practice, 75: 231-244.

Blundell, R., Bond, S. 1998. Initial conditions and moment restrictions in dynamic panel data models. Journal of Econometrics, 87: 11-143.

Borenstein, S. 1989. Hubs and high fares: dominance and market power in the US airline industry. RAND Journal of Economics, 20(3): 344-365.

Borenstein, S., Rose, N.L. 1994. Competition and price dispersion in the US airline industry. Journal of Political Economy, 102(4): 653-683.

Brueckner, J.K., Lee, D. Singer, E.S. 2013. Airline competition and domestic US airfares: A comprehensive reappraisal. Economics of Transportation, 2(1): 1-17.

Button, K. 2012. Is there any economic justification for high-speed railways in the United States? Journal of Transport Geography, 22: 300-302.

Canova, F., Ciccarelli, M. 2013. Panel Vector Autoregressive Models: A Survey. In Thomas B. Fomby, T.B., Kilian, L., Murphy, A. (ed.) VAR Models in Macroeconomics - New Developments and Applications: Essays in Honor of Christopher A. Sims (Advances in Econometrics, Volume 32), Emerald Group Publishing Limited, pp.205 - 246

Capozza, C. 2016. The effect of rail travel time on airline fares: first evidence from the Italian passenger market. Economics of Transportation, 6: 18-24.

Cooper, D. 1997. Barometric price leadership. International Journal of Industrial Organization, 15: 301-325.

Deneckere, R., Kovenock, D. 1992. Price leadership. Review of Economic Studies, 59: 143162.

Deng, C., Ma, Y., Chiang, Y. M. 2009. The Dynamic Behavior of Chinese Housing Prices. International Real Estate Review, 12(2): 121-134.

Eckert, A. 2003. Retail price cycles and the presence of small firms. Journal of Industrial Organization, 21: 151-170.

Enders, W. 2008. Applied econometric time series. John Wiley \& Sons.

Gaggero, A.A., Piga, C.A. 2010. Airline competition in the British Isles. Transportation Research Part E: Logistics and Transportation Review, 46(2): 270-279. 
Gaggero, A.A., Piga C.A. 2011. Airline Market Power and Inter-temporal Price Dispersion. Journal of Industrial Economics, 59(4): 552-577.

Granger, C.W.J. 1969. Investigating causal relations by econometric models and crossspectral methods. Econometrica 37: 424-438.

Graubner, M., Koller, I., Salhofer, K., Balmann, A. 2011. Cooperative versus non-cooperative spatial competition for milk. European Review of Agricultural Economics, 38(1): 99-118.

Hamilton, J.D. 1994. Time Series Analysis. Princeton, NJ: Princeton University Press.

Hannah, L., Kim, K.H., Mills, E.S. 1993. Land use controls and housing prices in Korea. Urban Studies, 30(1): 147-156.

Holtz-Eakin, D., Newey, W., Rosen, H. S. 1988. Estimating vector autoregressions with panel data. Econometrica, 56(6): 1371-1395.

Ishibashi, I. 2008. Collusive price leadership with capacity constraints. International Journal of Industrial Organization, 26(3): 704-715.

Kauffman, R.J., Wood, C.A. 2007. Follow the leader: price change timing in internet-based selling. Managerial and Decision Economics, 28(7): 679-700.

Lewis, M.S. 2012. Price leadership and coordination in retail gasoline markets with price cycles. International Journal of Industrial Organization, 30(4): 342-351.

Lutkepohl, H. 2005. New Introduction to Multiple Time Series Analysis. Berlin: SpringerVerlag.

Maskin, E., Tirole, J. 1988. A theory of dynamic oligopoly II: price competition, kinked demand curves and Edgeworth cycles. Econometrica, 56: 571-599.

Miller, N., Peng, L. 2006. Exploring metropolitan housing price volatility. Journal of Real Estate Finance and Economics, 33(1): 5-18.

Mouraviev, I., Rey, P. 2011. Collusion and leadership. International Journal of Industrial Organization, 29(6): 705-717.

Noel, M. 2007. Edgeworth Price Cycles: Evidence from the Toronto Retail Gasoline Market. Journal of Industrial Economics, 55(1): 69-92.

Noel, M. 2008. Edgeworth price cycles and focal prices: computational dynamic Markov equilibria. Journal of Economics and Management Strategy, 17: 345-377.

Perennes, P. 2014. Intermodal competition: studying the pricing strategy of the French rail monopoly. Transport Research Arena 2014, Paris, France <hal-01272287>.

Revoredo- Giha, C., Renwick, A. 2012. Retailers price behavior in the UK fresh fruit and vegetable market. Agribusiness, 28(4): 451-468.

Rotemberg, J.J., Saloner, G. 1990. Collusive price leadership. Journal of Industrial Economics, 39: 93-111.

Seaton, J.S., Waterson, M. 2013. Identifying and characterising price leadership in British supermarkets. International Journal of Industrial Organization, 31(5): 392-403.

Stavins, J. 2001. Price Discrimination in the Airline Market: The Effect of Market Concentration. Review of Economics and Statistics, 83(1): 200-202.

Wei, F., Chen, J., Zhang, L. 2014. Demand shocks, airline pricing, and high-speed rail substitution: Evidence from the Chinese market. Working paper, Sichuan Agricultural University, China. 